GLOAG, D. (1984) Unmet need in chronic disability. British Medical Journal, 289, 211-212.

Levin, H. S., Grossman, R. G., Rose, J. E. \& Teasdale, M. B. (1979) Long-term neuropsychological outcome of closed head injury. Journal of Neurosurgery, 50, 412-422.

Livingston, M. G. (1986) Assessment of need for coordinated approach in families with victims of head injury. British Medical Journal, 293, 742-744.

LoNDON, P. S. (1967) Some observations on the course of events after severe injury of the head. Annals of the Royal College of Surgeons, 41, 460-479.

MCCrendie, R. G., Oliver, A., Wilson, A. \& Burton, L. L. (1983) The Scottish Survey of "New Chronic" inpatients. British Journal of Psychiatry, 143, 564-572.

MCKinlay, W. W., BROOK, D. N., BOND, M. R., Martinage, D. P. \& Marshall, M. M. (1981) The short-term outcome of severe blunt head injury as reported by relatives of the head injured persons. Journal of Neurology, Neurosurgery and Psychiatry, 44, 527-533.

Medical Disability SocieTy (1988) The Management of Traumatic Brain Injury.

National Institute OF MeNTal Health (1987) Towards a Model Plan for a Comprehensive Community-based Mental Health System. Washington: NIMH.

ODDY, M. \& HuMPHREY, M. (1980) Social recovery during the year following severe head injury. Journal of Neurology, Neurosurgery and Psychiatry, 43, 798-802.

Royal College of Psychiatrists (1989) Report from the Public Policy Committee. Services for the Young Brain Damaged.

Strang, I., MacMillan, R. \& Jennetr, B. (1978) Scottish head injury management study. Injury, 10, 154-159.

Thomas, A. P., BAX, M. C. O. \& SMrTh, D. P. L. (1989) The health and social needs of young adults with physical disabilities. Clinical Development Needs, 106.

\section{Special Interest Groups}

In June 1987 Council approved the establishment of 'Special Interest Groups'.

Procedure for establishing a Special Interest Group:

(1) Any Member wishing to establish a Special Interest Group shall write to the Registrar with relevant details.

(2) The Registrar shall forward the application to Council.

(3) If Council approves the principal of establishing such a Special Interest Group then it will direct the Registrar to place a notice in the Bulletin or its equivalent, asking Members of the College to write in support of such a Group and expressing willingness to participate in its activities.

(4) If more than 50 Members reply to this notice, then Council shall formally approve the establishment of the Special Interest Group.
(5) The administrative support provided will be similar to that enjoyed by College Divisions. It should be noted therefore, that the college will maintain the list of members, prepare and distribute notice of meetings but will not provide staff to attend meetings, organise conferences etc.

In accordance with this procedure, Council has approved the establishment of a Management Special Interest Group. Members are invited to write in support of this Group and express willingness to participate in its activities. Members should write to Mrs Jean Wales at the College. If 50 members reply to this notice for the Group, then Council shall formally approve the establishment of this Special Interest Group.

Dr A. GATH Registrar

\section{Lundbeck Teaching Fellowship}

Fellows and Members of the Royal College of Psychiatrists, working overseas, are invited to apply for a Teaching Fellow from the UK to come to their country to provide a course of teaching in a designated specialist psychiatric subject. Overseas Fellows and Members may suggest a named teacher, but more importance will be given to the topic of their choice than to any individual.

A sum of $£ 5,000$ per year has been provided by Lundbeck Limited to cover the travel, living and incidental expenses of the Teaching Fellow who, it is envisaged, will complete the course over a period of 3-4 weeks. The host centre overseas will not be expected to provide any financial support.

Applications for 1992 should be sent to the Dean, The Royal College of Psychiatrists, 17 Belgrave Square, London SW1X 8PG. The Teaching Fellow will be selected by the Overseas Liaison Committee and his/her appointment ratified by the Court of Electors.

Dr Fiona CaldicotT Dean June 1991

\title{
The College Library
}

The Library will be closed from 3-12 August. During this period we regret that it will not be possible for

members to have access to the Library. Books may be returned to the College reception desk. 